\title{
Feminism and the Critique of Capitalism
}

\section{Abbey Zanger}

Graduate Representative Organization, The Johns Hopkins University

On April 24th and 25th, the Johns Hopkins University's Graduate Representative Organization held its spring symposium. This year's topic was "Feminism and the Critique of Capitalism." The conference, attended by about 400 people during the two days, was considered a great success by conference organizers.

Papers were presented by nationally and internationally known feminists. In the first session, Barbara Ehrenreich suggested that the current popularity of contemporary anti-feminism may derive from the 19th century feminist goal to make men more responsible within the family. Barbara Winslow followed Barbara Ehrenreich, arguing that these movements can be resisted, as they have been historically, by feminists organizing as and with working class women around economic and political needs.

Second session contributors discussed the relationship between patriarchy and capitalism. Zillah Eisenstein identified a radical potential within liberal feminism, which she sees as a tradition capable of undermining patriarchy as it operates at a state level. Like Eisenstein, Nancy Hartsock addressed the nature of the Western State and suggested that "because the construction of political life is rooted in male sexuality, and because male sexuality is historically linked with violence and death, political life has . . . been most fundamentally concerned with making war and creating structures for domination." Julia Ericksen examined the interrelationship between women's position in the labor force and their position in the home.

The third session began with Joan Smith, who argued the necessity of viewing working class, sex and race as part of the unity of the structure of capitalism. Marx, she observed, did have the beginnings of a theory of the family and of women's oppression-a theory which must be developed today by first analyzing the relationship between production and reproduction. She sees this relationship being restructured in the current crisis by state and new right attacks on women; thus the fight against these attacks has to be a mass political attack against the state. Natalie Sokoloff followed with a documentation of the attacks against women-attacks on women's reproductive freedom, the so-called "protection of 
the family," and attacks on affirmative action. She discussed some of the effects of these attacks on women's position in the labor market and in the family.

The next paper, by Kersti Yllo and Murray Straus, examined violence against women. Their empirical research showed that wife beating in America is most prevalent in states where the legal, political and educational status of women is lowest, declining as the status of women rises, but increasing again where the status of women is highest. Finally, Meredeth Turshen discussed the situation of Third World women. The global economic crisis affects the Third World more seriously than the developed world, and within the Third World it affects women more than men. Turshen stressed the necessity of First World women's solidarity with Third World women actively involved in struggle-South Africa, El Salvador, Eritrea, Palestine.

The fourth session featured representatives from a number of groups. These included the D.C. Area Feminist Alliance; Women: A Journal of Liberation; D.C. Rape Crisis Center; the Women's Union of Baltimore; and the Johns Hopkins Employees Association. A discussion followed, centering on whether women should struggle for change through electoral politics or whether the struggle should be revolutionary and focused on getting women into the streets. The debate continues. 